\title{
DETERMINATION OF THIAMINE HYDROCHLORIDE AND PYRIDOXINE HYDROCHLORIDE ON RICE WITH WASHING, MILLING AND POUNDING BY SPECTROMETRIC METHODS
}

\author{
${ }^{1}$ Edy Agustian Yazid, ${ }^{2}$ Damar Pasunaring Ati, ${ }^{3}$ Aulia Mahardika \\ ${ }^{1,2,3}$ Department of Chemistry, Delima Husada College of Health Analyst, \\ Jl. Arief Rahman Hakim No. 2B, Gresik, Indonesia \\ *Corresponding author: estien_y@yahoo.co.id \\ Co-author: damarpasunaringati7@gmail.com \\ Co-author: auliamahardika87@gmail.com
}

\begin{abstract}
Rice is a principal food source for most of the world's population. Rice has many nutrients including thiamin hydrocloride (THC) and pyrodoxine hydrocloride (PHC). Before consumption, rice is usually processed such as milling, washing, and cooking. Determination of THC on IR-64 and Rojolele rice with washing three times has been conducted. Also determined of PHC on the milled IR-64 rice and the pounded IR-64 rice. The THC was determined by spectrophotometric method at $246 \mathrm{~nm}$. Determination of PHC based on the coupling reaction with diazo reagent in alkaline solution to form azo dye then the absorption was measured at $440 \mathrm{~nm}$. The result of determination of THC on IR-64 and Rojolele rice after washing three times can decrease THC level $12,93 \%$ and $12,88 \%$ respectively. Determination of PHC on the milled IR-64 rice obtained $1.54 \pm 0.027 \mu \mathrm{g} / \mathrm{g}$ and on the pounded IR-64 rice $1.80 \pm 0.048 \mu \mathrm{g} / \mathrm{g}$. The result of statistical test with independent $T$ test showed there were significant difference $(\alpha=0,05)$ PHC level on both treatments.
\end{abstract}

Keywords: Thiamine hydrochloride, pyridoxine hydrochloride, rice, washing, milling, pounding

\section{INTRODUCTION}

Rice is a principal food source for most of the world's population, especially in Asia [1]. Rice consumption in Indonesia reached $95 \%$ of the population as a functional food ingredient [2]. As a principal food of rice can be processed into rice, various types of cakes or traditional foods in the form of rice flour [3]. Rice is a grain of rice that has been removed from the outer shell with milled or pounded [4].

Based on the color and texture there are three types of rice namely glutinous rice, brown rice and white rice [5]. In Indonesia, the most consumed rice is white rice [6] . There are several variants of white rice on the market, including Pandan Wangi rice, Setra Ramos 
rice (IR-64), Rojolele rice and IR-42 rice. Type of IR-64 and Rojolele rice most often consumed by the community because the price is cheap and if cooked not quickly stale.

Rice is a source of energy, rich in protein, vitamin B complex and minerals for the body. The largest nutrient content in rice is dominated by starch about 80-85\% [7]. Vitamin B complex contained in rice such as vitamin $\mathrm{B}_{1}$ (thiamine hydrocloride, THC) and vitamin $\mathrm{B}_{6}$ (pyrodoxine hydrocloride, PHC). Sources of THC and PHC are commonly found in nuts, beans, meat, fish, egg yolk, milk, and seralia such as rice and wheat [8].

THC has a role as a coenzyme and various energy metabolism reactions. THC is needed to raise appetite, normal growth and play a role in the development of the brain and nervous system [9]. This vitamin is also reported to reduce the damage caused by free radicals and prevent the occurrence of degenerative diseases [10]. PHC has three main forms, namely pyridoxine, pyridoxal, and pyridoxamine. In the liver, this vitamin is converted to pyridoxal 5-phosphate (PLP) which is a cofactor in various reactions of amino acid metabolism. PLP also plays a role in enzymatic reactions to release glucose from glycogen and neurotransmitter synthesis [11].

The daily requirement of vitamins depends on the age, gender and type of work [12]. Deficiency of THC can lead to the occurrence of beri-beri disease, especially countries that use rice staple food. In addition, deficiency of THC can lead to various neurological symptoms and cardiovascular symptoms. Early symptoms such as fatigue, weakness and emotional distress. Prolonged deficiency may cause polneuritis and heart failure or peripheral edema [13]. Deficiencies of PHC are manifested as dermatologic, circulatory, and neurologic changes [14].

Rice to become ready-to-eat food requires several stages of processing such as milling, washing, and cooking. In the process of washing can lead to reduced levels of THC in rice before cooking [15]. THC and PHC are water-soluble and unstable in storage or processing [16].

Determination of THC has been widely performed like using the method of High Performance Liquid Chromatography [17], electrochemical injection flow [9], alkalimetry [18] and spectrophotometry [19]. PHC uses methods such as High Performance Liquid Chromatography [20], Charge transfer complexation [21] and spectrophotometry [22]. The advantages of spectrophotometry are simple, fast, specific and sensitive [23]. Purpose of this 
research is to know THC level on IR-64 and Rojolele rice after washing. Also to know the level of PHC on the milled IR-64 rice and the pounded IR-64 rice.

\section{MATERIAL AND METHOD}

\section{Material}

All reagents and chemicals used were of analytical grade and all solutions were prepared from double distilled water. THC and PHC was obtained from Sigma-Aldrich (China), sulfanilic acic (merck), sodium nitrite (merck), sodium hydroxide (merck), hydrochloric acid, whatman No.1 filter paper, IR-64 and Rojolele rice taken directly from the rice seller in Gresik city.

\section{Instruments}

Spectrophotometer UV-1600 PC (singgle beam), with $1 \mathrm{~cm}$ matched quartz cells was used for absorption measurement, analytical balance, hot plate, magnetic stirer, and a set of glassware.

\section{PROCEDURE}

\section{Reagents and solutions}

Hydrochloric acid solution (6.0 N). This solution was prepared by diluting $50 \mathrm{~mL}$ of concentrated hydrochloric acid to a $100 \mathrm{~mL}$ double distilled water in a volumetric flask. Hydrochloric acid solution $(0.1 \mathrm{~N})$ was prepared from $\mathrm{HCl} 6.0 \mathrm{~N}$ solution.

Diazo reagent. This solution was prepared by dissolving sulfanilic acid with $\mathrm{HCl} 6 \mathrm{~N}$ and adding the double distilled water to $100 \mathrm{~mL}$ in a volumetric flask.

Sodium nitrite solution (1 \%). This solution was prepared by dissolving $1.0000 \mathrm{~g}$ of sodium nitrite in $100 \mathrm{~mL}$ double distilled water in volumetric flask.

Sodium hydroxide solution (3.0 M). This solution was prepared by dissolving $12 \mathrm{~g}$ of sodium hydroxide in double distilled water and adding the double distilled water to $100 \mathrm{~mL}$ in a volumetric flask.

Working THC solution $(500 \mu \mathbf{g} / \mathbf{m L})$. This solution was prepared by dissolving $0.2500 \mathrm{~g}$ of THC in double distilled water and adding the double distilled water to $500 \mathrm{~mL}$ in a volumetric flask. THC solution $(250 \mu \mathrm{g} / \mathrm{mL})$ was prepared from $500 \mu \mathrm{g} / \mathrm{mL}$ stock solution.

Working PHC Solution $(\mathbf{1 0 0} \boldsymbol{\mu g} / \mathbf{m l})$. This solution was prepared by dissolve an accurately $0.0100 \mathrm{~g}$ of PHC in double distilled water and adding to $100 \mathrm{~mL}$ in a volumetric flask.

\section{Calibration Curve of THC.}

J. Islamic Pharm., an open access journal ISSN : 2527-6123 
Standard solution of THC was prepared with a range concentration of $5-25 \mu \mathrm{g} / \mathrm{mL}$. THC standard solution were transferred into a series $25 \mathrm{~mL}$ volumetric flask. This solution was diluted with $0.1 \mathrm{~N} \mathrm{HCl}$ to the boundary mark and then the absorbance was measured at a 246 $\mathrm{nm}$.

\section{Callibration Curve of PHC}

The diazo reagent $(2.0 \mathrm{ml})$ was transferred into a $25 \mathrm{ml}$ volumetric flask and added $1.0 \mathrm{ml}$ of $1 \% \mathrm{NaNO}_{2}$ solution, then mixed homogenously and allowed to stand for 1 minute while occasionally shaking. Subsequently, the mixture was added $5 \mathrm{ml}$ of PHC standard solution $(4.0-20 \mu \mathrm{g} / \mathrm{mL})$ and $1.0 \mathrm{ml}$ of $3 \mathrm{~N} \mathrm{NaOH}$ solution then allowed to stand for 10 minutes at room temperature. The volume of the solution is diluted with double distilled water and mixed well. The absorbance of the solution was measured at $400 \mathrm{~nm}$ using a reagent blank.

\section{Rice washing water}

A certain amount of IR-64 and Rojolele rice samples were weighed and transferred into a beaker glass with the addition of double distilled water. The mixture was stirred using a glass stir bar for 30 seconds then filtered using Whatman No.1 filter paper. The wash water of rice was collected and transferred in a $100 \mathrm{~mL}$ volumetrik flask and diluted with double distilled water to the boundary mark.

\section{Rice sample}

The preparation of rice sample was conducted according the Sudarmadji's method [24], with slight modification. Rice is milled with a grinding machine and partially pounded with pestle and mortar and then pollinated into flour. A certain amount of rice flour weighed and transferred into a beaker and $90 \mathrm{ml}$ of $0.1 \mathrm{~N} \mathrm{HCl}$ was added. The mixture was heated for 30 minutes at $100{ }^{\circ} \mathrm{C}$ in a water bath while stirring. After cool, the solution was filtered with Whatman No. 1 filter paper. The filtrate was transferred to a $100 \mathrm{ml}$ volumetric flask and diluted with $0.1 \mathrm{~N} \mathrm{HCl}$ to the marker boundary.

\section{Determination of THC}

The THC level was determined using Rohman's proposed method [18], with slight modification. The rice washing water $(5.0 \mathrm{~mL})$ was transferred in a $25 \mathrm{ml}$ volumetric flask and diluted with $0.1 \mathrm{~N} \mathrm{HCl}$ until the boundary marker. The solution was measured by UV1600 spectrophotometer at $246 \mathrm{~nm}$ wavelength using reagent blank.

\section{Determination of PHC}


The levels of PHC was determined using diazotization method with modification [25]. The diazo reagent $(2.0 \mathrm{ml})$ was transferred into a $25 \mathrm{ml}$ volumetric flask and added $1.0 \mathrm{ml}$ of $1 \%$ $\mathrm{NaNO}_{2}$ solution, then mixed and allowed to stand for 1 minute while occasionally shaking. Subsequently, the mixture was added $5 \mathrm{ml}$ of rice sample and $1.0 \mathrm{ml}$ of $3 \mathrm{~N} \mathrm{NaOH}$ solution then shaken and allowed to stand for 10 minutes at room temperature. The solution was diluted with double distilled water and mixed well. The absorbance of the solution was measured at $400 \mathrm{~nm}$ using a reagent blank.

\section{RESULT AND DISCUSSION}

\section{Determination of Maximum Wavelength}

Before to the analysis of THC and PHC on rice, the maximum wavelength was determined. It aims to obtain the wavelength that has the maximum sensitivity and absorbance. Measurements were made by reading the absorbance of THC standard solution using UV1600 PC sectrophotometer at wavelength $200-400 \mathrm{~nm}$. The measurement results obtained maximum absorbance at $246 \mathrm{~nm}$. In the standard solution PHC measured at 400-800 nm and obtained a maximum wavelength of $440 \mathrm{~nm}$. Each of these wavelengths is used for the determination of THC and PHC on the rice sample.

\section{Calibration Curve}

The calibration curve of THC standard solution was obtained good a linear curve according to Lambert-Beer law in the concentration range $5-25 \mu \mathrm{g} / \mathrm{mL}$. Based on the curve (Fig. 1), obtained regression equation $\mathrm{y}=0.2014 \mathrm{x}+0.003$ and the correlation coefficient $(\mathrm{r})=0.9999$. Meanwhile, the calibration curve of standard solution PHC was obtained linear in the concentration range 4-20 $\mu \mathrm{g} / \mathrm{mL}$. From the curve (Fig. 2) obtained regression equation y $=$ $0.0898 x-0.0262$ and correlation coefficient 0,9904 . In both calibration curves obtained correlation coefficient value close to one. According Harmita [26], it shows there is a correlation between the concentration of standard solution with absorbance.

\section{Determination of THC}

Determination of THC levels was performed on the wash water of IR-64 and Rojolele rice. Each was washed three times, then the washing water was collected for analysis. Every time the washing is done by stirring using a stir bar for half a minute. The duration of stirring is taken from people's habit in general when washing rice before cooking. The result of 
determination of THC level on the wah water of IR-64 and Rojolele rice is shown in Table 1 and Table 2.

Based on Table 1 and Table 2 are obtained the average THC levels on the wash water of IR64 rice with washing once was $0.1821 \pm 0.0012 \mu \mathrm{g} / \mathrm{g}$, twice $0.2825 \pm 0.0020 \mu \mathrm{g} / \mathrm{g}$ and three times $0.3258 \pm 0.0015 \mu \mathrm{g} / \mathrm{g}$. While on the wash water Rojolele rice was obtained THC levels by washing once $0.1925 \pm 0.0019 \mu \mathrm{g} / \mathrm{g}$, twice $0.2142 \pm 0.0025 \mu \mathrm{g} / \mathrm{g}$, and three times $0.3538 \pm$ $0.0020 \mu \mathrm{g} / \mathrm{g}$. From these results it can be seen that the more the number of washing more and more amount of THC dissolved in washing water. Vitamin $\mathrm{B}_{1}$ (THC) is water soluble and THC content is widely present in aleurone in the surface layer of rice [15]. When rice washed THC on rice, especially on aleurone, it was carried along with water solvent. In the process of washing can reduce THC levels in rice before consumption [27]. Increase of THC levels in IR-64 rice washing water and Rojolele rice is shown in Figure 3. While the decrease of THC levels in IR-64 rice and Rojolele rice is shown in Figure 4.

In addition, the THC levels in rice without washing were also investigated (Table 3). THC levels in IR-64 and Rojolele rice were $2.520 \pm 0.006 \mu \mathrm{g} / \mathrm{g}$ and $2.746 \pm 0.008 \mu \mathrm{g} / \mathrm{g}$ respectively. From these results it can be seen that THC levels in Rojolele rice yields are slightly larger than IR-64 rice. However, THC levels in both types of rice is still slightly below THC levels in 30 varieties of rice from Philiphina as Villareal and Juliano reported [28]. The range of THC content obtained between $2.85-5.2 \mu \mathrm{g} / \mathrm{g}$ or $0.285-0.52 \mathrm{mg} / 100 \mathrm{~g}$. While, results of research Kennedy and Burlingame [29] reported, that the thiamine content range of 79 rice varieties was $0.117-1.74 \mathrm{mg} / 100 \mathrm{~g}$, averaging $0.457 \mathrm{mg} / 100 \mathrm{~g}$ and the largest difference among varieties $1.6 \mathrm{mg} / 100 \mathrm{~g}$. In this study rice after washing three times on both types of rice respectively decreased of THC levels. The graph of decreasing THC levels with both types of rice is shown in Figure 4.

From Table 3 it can be seen that the more washing of IR-64 and Rojolele rice, the more THC decreases in rice. The percentage of THC decrease after washing three times resulted in IR64 rice of $12.93 \%$, and Rojolele rice was $12.88 \%$.

THC is one type of vitamins are very unstable. The THC stability in the material is influenced by several factors such as $\mathrm{pH}$, temperature and treatment method. Some rice processing before consumption can be through milling, pulverization, washing, and duration of washing. These factors are very influential to reduce THC levels in food. Washing is an important factor that can accelerate the occurrence of THC solubility in laundry water, 
thereby reducing THC levels in rice. According Andarwulan [16], before cooked rice undergoes treatment through milling, pounding dan washing process can reduce THC levels.

\section{PHC with Milling and Pounding}

Determination of PHC level was done on the milled IR-64 rice and the pounded IR-64 rice. The milled rice was produced from rice processing by grinding machine. Rice is produced through the process of pounding rice using pestle and mortar. The results of PHC levels on the IR-64 rice milled and pounded are listed in Table 4.

The average results of PHC level on the milled and the pounded IR-64 eice were $1.54 \pm 0.027$ $\mu \mathrm{g} / \mathrm{g}$ and $1.80 \pm 0.048 \mu \mathrm{g} / \mathrm{g}$, respectively (Table 4). From these results, the levels of PHC on the pounded IR-64 rice is higher than the milled IR-64 rice. The result of statistical analysis through the Independent-Samples $\mathrm{T}$ test with SPSS 16 for Window program, there are significant differences $(\alpha=0,05)$ PHC level between the milled IR-64 rice and pounded IR64 rice.

Rice grains before becoming rice undergo processing such as the milling or pounding. The nutrient content of the IR-64 rice including PHC is mostly found in aleuron [18]. During the rice milling process, the aleurone present in the IR-64 rice will be lost by the exfoliating process through the machine until it becomes white rice. The loss of aleurone will be accompanied by a decrease in the amount of PHC present in rice. The pounded IR-64 rice produces a slightly brownish color and does not remove aleurone entirely, thereby lowering only a small amount of PHC in the rice. Rice pounding process is generally done in many rural areas. Rice through the milling process is most in demand by the community because it is considered clean white rice and has a better taste for consumption.

\section{CONCLUSION}

Based on this study, the THC levels on IR-64 and Rojolele rice after washing three times decreased THC levels $12.93 \%$ and $12.88 \%$, respectively. Whereas the PHC levels on the milled IR-64 rice and the pounded IR-64 rice are $1.54 \pm 0.027 \mu \mathrm{g} / \mathrm{g}$ and $1.80 \pm 0.048 \mu \mathrm{g} / \mathrm{g}$ respectively. From these results it can be concluded that more washing in IR-64 rice, can reduce THC levels. The levels of PHC on the pounded IR-64 rice is higher yield than milled rice.

J. Islamic Pharm., an open access journal ISSN : 2527-6123 


\section{ACKNOWLEDGMENT}

The author would like to thank the Laboratory of Delima Husada College of Health Analysts by the availability of the equipment and reagents for the conduct of this research.

\section{REFERENCES}

[1] Schwartz, S.J. 1991. World Rise Trade: Prospects and Issue for the Nineties. Rice Situation and Outlook Report, USDA Economic Research Service.

[2] Widjayanti, E. 2004. Potential and Prospect of Indigenous Indonesian Functional Food. National Food Colloquium, Bandung.

[3] Tien, R.M., Sugiyono, Fitriyono, A. 2010. Knowledge of Food. Alfabeta, Bogor: pp. 277-282.

[4] Indrasari S.D, Wibowo P, and Ardhiyanti S.D. 2011. Evaluation of Nutritional Quality and Acidity of Folic Acid Several Red Rice Chaffs. Proceedings of Indonesian Center for Rice Research, Bogor: pp.1293-1300.

[5] Putra, S. 2010. Exploration and Characterization of Red Rice Germplasm Plasma in Solok Regency of West Sumatra. Thesis Undergraduate Degree, Faculty of Agriculture Andalas University, Padang.

[6] Made, O.A. 2001. Application of the Nerlove Partial Adjustment Model in Production Projection and Rice Consumption. Center for Food Crops $R \& D$, Bogor.

[7] Gealy, David R and Bryant RJ. 2009. Seed Physicochemical Characteristics of Fieldgrown US Weedy Rice (Oryza sativa) Biotypes: Contrasts with Commercial Cultivars. Journal of Cereal Science, 49:239-245.

[8] Almatsier S. 2009. Basic Principles of Nutrition Science. Gramedia Pustaka Utama, Jakarta: pp. 213-220

[9] Norouzi, T., Garakani, M., Rashedi, H.A. Zamani, M.R., Ganjali. 2010. Ultrasensitive Flow-Injection Electrochemical Method Using Fast Fourier Transform Square-Wave Voltammetry for Detection of Vitamin $\mathrm{B}_{1}$. International Journal of Electrochemistry Science, 5: 639 - 652.

[10] Lynch P.L, Young I.S. 2000. Determination Of Thiamine by High Performance Liquid Chromatography. Journal of Chromatography, 881:267-84.

[11] Bhagwat G.B. 2013. UV-Spectrophotometric Analysis of Prochlorperazine Maleate and Pyridoxine in Tablet Dosage Form. International Journal of Chemistry, 5(5):2309-16.

[12] Murray, R.K., Granner, D.K., Mayes, P.A., Rodwell, V.W. 1997. Harper Biochemistry. $24^{\text {th }}$ Ed, Medical Book Publishers EGC, Jakarta.

[13] Thomson, A.D. 2000. Mechanisms of Vitamin Deficiency in Chronic Alcohol Misusers and The Development of The Wernicke-Korsakoff Syndrome. International Journal of Pharmacy and Pharmaceutical Sciences, 35(1):2-7.

[14] Niraimathi, V., Jerad, S.A, Nanjappan, K. 2010. Spectrophotometric Estimation of Nislodipine in Bulk and Tablet Dosage Formulation. Acta Ciencia Indica, 36(4): 393.

[15] Tjiptadi, W. 1982. Rice and Processing. Faculty of Agricultural Technology, IPB Bogor.

[16] Andarwulan, N and Koswara, SK. 1992. Chemical Vitamins, Rajawali Press, Jakarta: pp. 215-220. 
[17] Novi T.N., Widowati, D., Wartini., Aryani, T. 2011. Validation of HPLC Method for Determination of Thiamine Hydrochloride, Riboflavin, Nicotinamide, and Pyridoxine Hydrochloride in Syrup Preparation. Canadian Journal on Scientific and Industrial Research, 7: 269-274.

[18] Rohman, A. 2007. Chemical Pharmaceutical Analysis. Pustaka Pelajar. Yogyakarta: pp.157-160.

[19] Manohar, SD, Sridhar, D.A, Allikarjuna, S.C. 2013. Development of UV Spectrophotometric Method for Estimation of Carvedilol in Bulk and Pharmaceutical Formulations. Asian Journal of Research Chemistry, 10:111-118.

[20] Pathak, A., Rajput, S. (2008). Simultaneous Determination Of Ternary Mixture Of Pyridoxine Hydrochloride, Doxylamine Succinate and Folic Acid by a Ratio Spectra Zero Crossing, Double Divisor-Ratio Spectra Derivative and Column HPLC Methods. Journal of AOAC International, 91(5):1059-1069.

[21] Raza, A., Ansari. T., Niazi, S., Rehman, A. 2007. Spectrophotometric Determination of Pyridoxine Hydrochloride (Vitamin $\mathrm{B}_{6}$ ) in Bulk and Tablets by Charge-Transfer Complexation with Chloranil. Journal of Chemical Society of Pakistan, 29(1):33-36.

[22] Smita, C.N, Preeti, V., Kulkarni., Bhaskar, V., Chavhan, V. 2013. Development and Validation of UV Spectrophotometric Method for Simultaneous Estimation of Doxylamine Succinate and Pyridoxine Hydrochloride in Bulk and Tablet Dosage Form, International Journal of Pharmacy and Pharmaceutical Sciences, 5(3):390-393.

[23] Kaynak. M. S. and Sahin. S.A. 2008. New HPLC Approach for Determination of InVitro Solubility of Naproxen Sodium Hacettepe. University Journal of the Faculty of Pharmacy, 28(1):49-62.

[24] Sudarmadji, Haryono, B., and Suhardi. 1997. Analytical Procedures for Food and Agricultural Materials. Liberty, Yogyakarta.

[25] Auterhoff dan Kovar. 2002. Identify of Drugs. ITB, Bandung: pp. 169-170.

[26] Harmita. 2004. Implementation Instructions Validation Method and Method Calculation. Pharmaceutical Science, Magazine of Indonesia University, 3:117-134.

[27] Sediaoetama, A.D. 2004. Nutrition Science, 5th Ed, Dian Rakyat, Jakarta

[28] Villareal, C and B. Juliano. 1989. Variability in contents of thiamin and riboflavin in brown rice, crude oil in brown rice and bran-polish, and silicon in hull of IR rices. Plants Foods for Human Nutrition, 39:287-297.

[29] Kennedy, G and Burlingame, B. 2003. Analysis Of Food Composition Data on Rice From A Plant Genetic Resources Perspective. Journal Food Chemistry, 80:589-596. 
Table 1. Levels of THC in the IR-64 rice washing water

\begin{tabular}{ccccccc}
\hline $\begin{array}{c}\text { Amount of } \\
\text { Washing (Time) }\end{array}$ & $\mathbf{3}$ & $\mathbf{2}$ & $\mathbf{3}$ & $\begin{array}{c}\text { Average } \\
(\boldsymbol{\mu} \mathbf{g} / \mathbf{m L})\end{array}$ & $\begin{array}{c}\text { Levels of THC } \\
(\boldsymbol{\mu} \mathbf{g} / \mathbf{g})\end{array}$ & $\begin{array}{c}\text { SD } \\
(\mathbf{n}=\mathbf{3})\end{array}$ \\
\hline 1 & 0.145 & 0.147 & 0.145 & 0.146 & 0.1821 & 0.0012 \\
\hline 3 & 0.228 & 0.226 & 0.224 & 0.226 & 0.2825 & 0.0020 \\
\hline 3 & 0.261 & 0.262 & 0.259 & 0.261 & 0.3258 & 0.0015 \\
\hline
\end{tabular}

$\mathrm{C}$ is consentration of THC obtained from the standard curve

Table 2. Levels of THC in the Rojolele rice washing water

\begin{tabular}{ccccccc}
\hline \multirow{2}{*}{$\begin{array}{c}\text { Amount of Washing } \\
\text { (Time) }\end{array}$} & \multicolumn{3}{c}{$\mathbf{C}(\boldsymbol{\mu g} / \mathbf{m L})$} & $\begin{array}{c}\text { Average } \\
(\boldsymbol{\mu} \mathbf{g} / \mathbf{m L})\end{array}$ & $\begin{array}{c}\text { Levels of THC } \\
(\boldsymbol{\mu} \mathbf{g} / \mathbf{g})\end{array}$ & $\begin{array}{c}\text { SD } \\
(\mathbf{n}=\mathbf{3})\end{array}$ \\
\hline 1 & 0.154 & 0.152 & 0.156 & 0.154 & 0.1925 & 0.0019 \\
\hline 2 & 0.174 & 0.171 & 0.169 & 0.171 & 0.2142 & 0.0025 \\
\hline 3 & 0.285 & 0.283 & 0.281 & 0.283 & 0.3538 & 0.0020 \\
\hline
\end{tabular}

$\mathrm{C}$ is consentration of THC obtained from the standard curve

Table 3. Percentage of THC decrease on IR64 and Rojolele rice after washing

\begin{tabular}{ccccc}
\hline \multirow{2}{*}{$\begin{array}{c}\text { Amount of } \\
\text { Washing (Time) }\end{array}$} & \multicolumn{2}{c}{ Levels of THC in Rice $(\% \mathbf{~ m g} / \mathbf{g})$} & \multicolumn{2}{c}{ Decrease of THC in Rice (\%) } \\
\cline { 2 - 5 } & IR-64 & Rojolele & IR-64 & Rojolele \\
\hline 0 & $2.520 \pm 0.006$ & $2.746 \pm 0.008$ & $*$ & $*$ \\
\hline 1 & $2.338 \pm 0.001$ & $2.554 \pm 0.002$ & 7.23 & 7.01 \\
\hline 2 & $2.238 \pm 0.002$ & $2.532 \pm 0.003$ & 11.21 & 7.80 \\
\hline 3 & $2.194 \pm 0.002$ & $2.393 \pm 0.002$ & 12.93 & 12.88 \\
\hline
\end{tabular}

The data presented are mean value of three repetitions of \pm standard deviation ( $n=3 \pm$ s.d.).

*Not evaluated.

Table 4. Levels of PHC on the IR-64 rice milled and pounded

\begin{tabular}{ccc}
\hline Type of IR-64 Rice & Levels of PHC $(\mu \mathrm{g} / \mathbf{g})$ & SD $(\mathbf{n}=\mathbf{1 0})$ \\
\hline Milled & 1.54 & 0.027 \\
Pounded & 1.80 & 0.048 \\
\hline
\end{tabular}


The data presented are mean value of ten repetitions

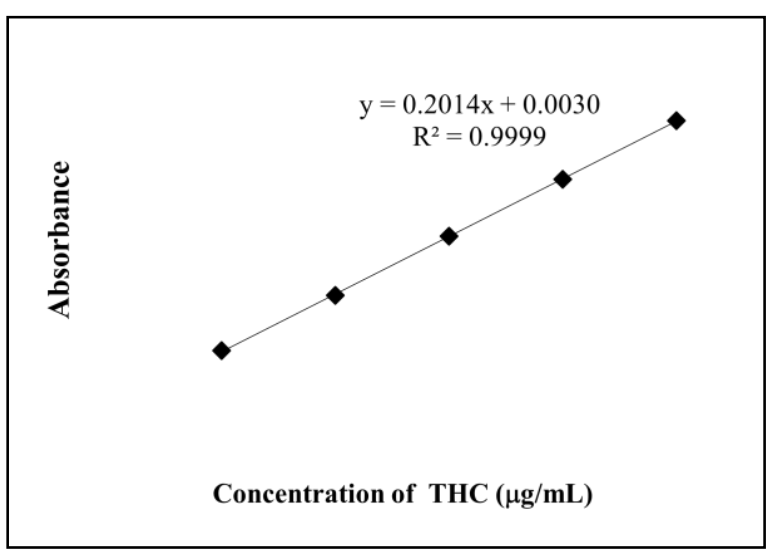

Figure 1. Calibration curve of THC

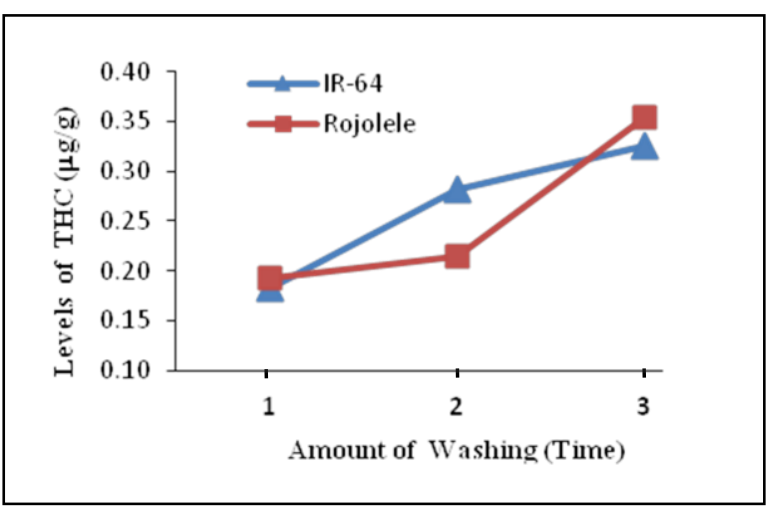

Figure 3. Increase of THC levels on the IR-64 and Rojolele rice washing water

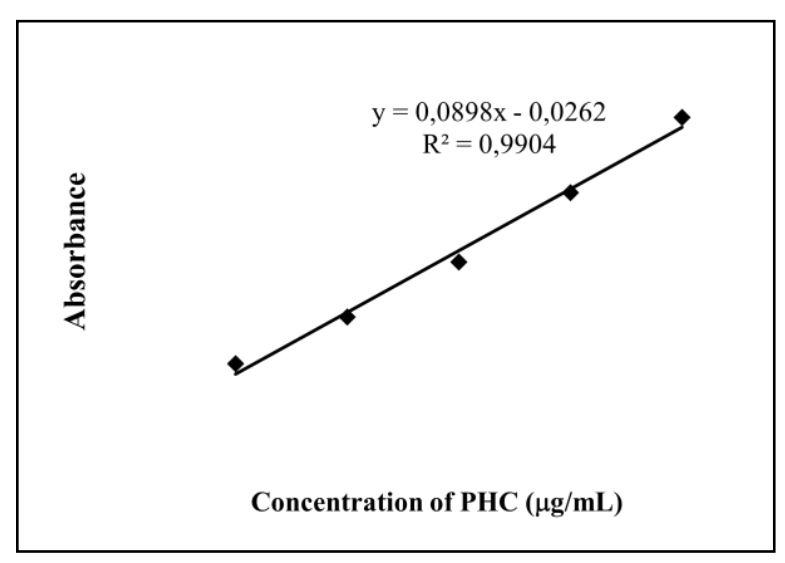

Figure 2. Calibration curve of PHC

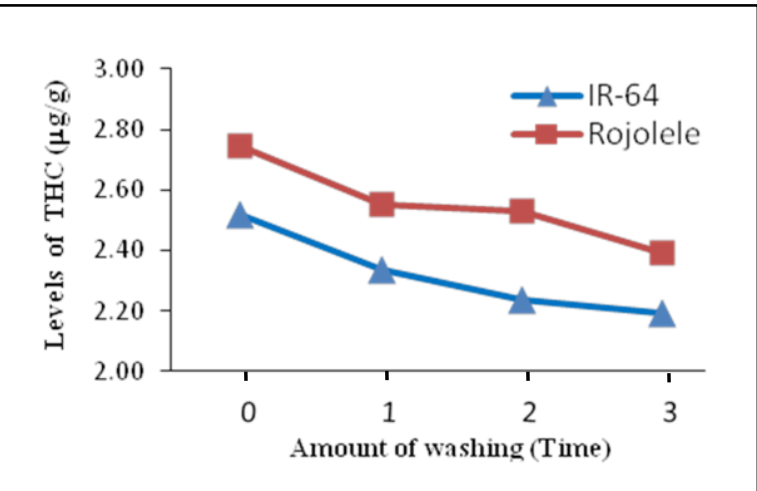

Figure 4. Decrease of THC levels on the IR-64 and Rojolele rice after washing 